\title{
Pancoast tumour
}

\author{
Deepwant Singh, Bhathiya Wijeyekoon
}

Department of Rheumatology, East and North Hertfordshire NHS Trust, Stevenage, UK

Correspondence to Dr Bhathiya Wijeyekoon, j.wijeyekoon@nhs.net

\section{DESCRIPTION}

A 61-year-old man was referred to our rheumatology unit with a 3-month history of worsening left-sided neck and shoulder pain. His general practitioner (GP) suspected Giant cell arteritis and a temporal artery biopsy was performed which was negative. Shoulder and neck x-rays were also normal. He had a 40-pack-year smoking history and a chest radiograph was organised by his GP. On questioning, he admitted to significant weight loss and hoarseness of voice.

On examination, shoulder movements did not exacerbate his pain and he had a full range of shoulder and upper-limb movements. He had a left Horner's syndrome, a cyanosed left forearm with feebly palpable left upperlimb pulses. The temporal arteries were non-tender. Chest examination was unremarkable. His erythrocyte sedimentation rate and C-reactive protein level were raised at $30 \mathrm{~mm} / \mathrm{h}$ and $60 \mathrm{mg} / \mathrm{l}$, respectively. Other blood tests were unremarkable.

A chest radiograph (figure 1) showed slight right-sided tracheal deviation and subtle non-homogenous left upper-
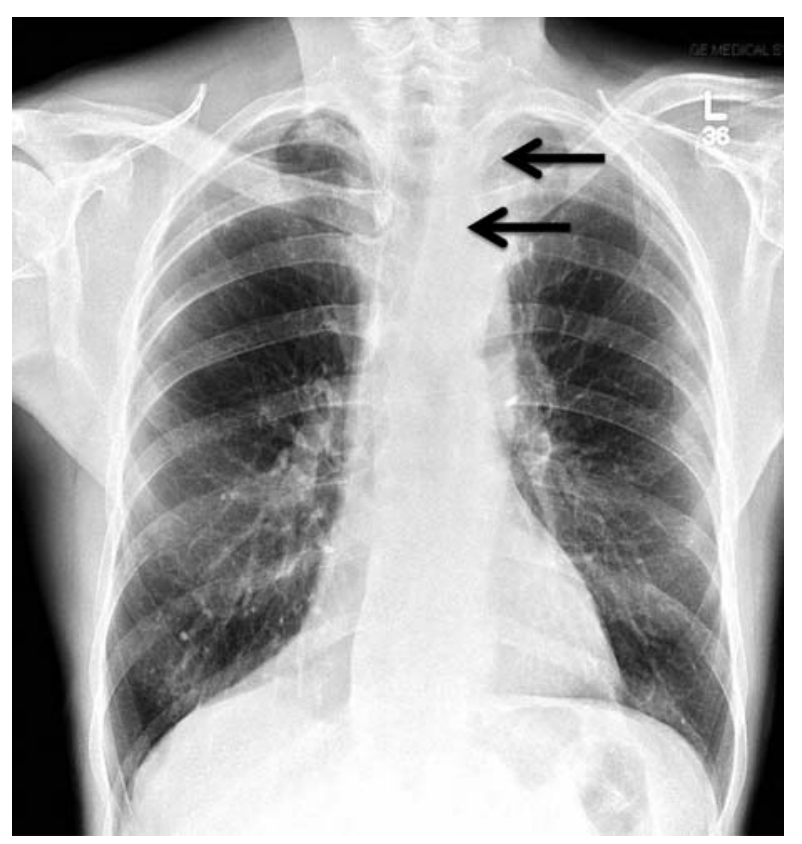

Figure 1 Chest radiograph with slight right tracheal deviation and subtle non-homogenous opacity in left upper zone (black arrows). lobe opacity. The history and clinical features along with radiological findings were highly suggestive of a left apical lung lesion. An urgent enhanced CT scan of the thorax (figures 2 and 3 ) was arranged and demonstrated a soft-tissue mass $(6.9 \mathrm{~cm} \times 5.4 \mathrm{~cm} \times 7.7 \mathrm{~cm})$ in the left lung apex encasing the left subclavian artery.

Of the patients presenting with a Pancoast tumour, $1.7 \%$ have a normal plain chest radiograph. ${ }^{1}$ Our case illustrates that when there is a high index of clinical suspicion, CT imaging should be undertaken to exclude a Pancoast tumour even when the plain radiograph changes are subtle.

Shoulder pain has been reported as being the first presenting feature of a Pancoast tumour in $90 \%$ of cases. ${ }^{2}$ It is of interest that the original description of a Pancoast tumour in 1932 by Henry Pancoast ${ }^{3}$ was of shoulder pain due to an apical mass.

Competing interests None.

Patient consent Obtained.

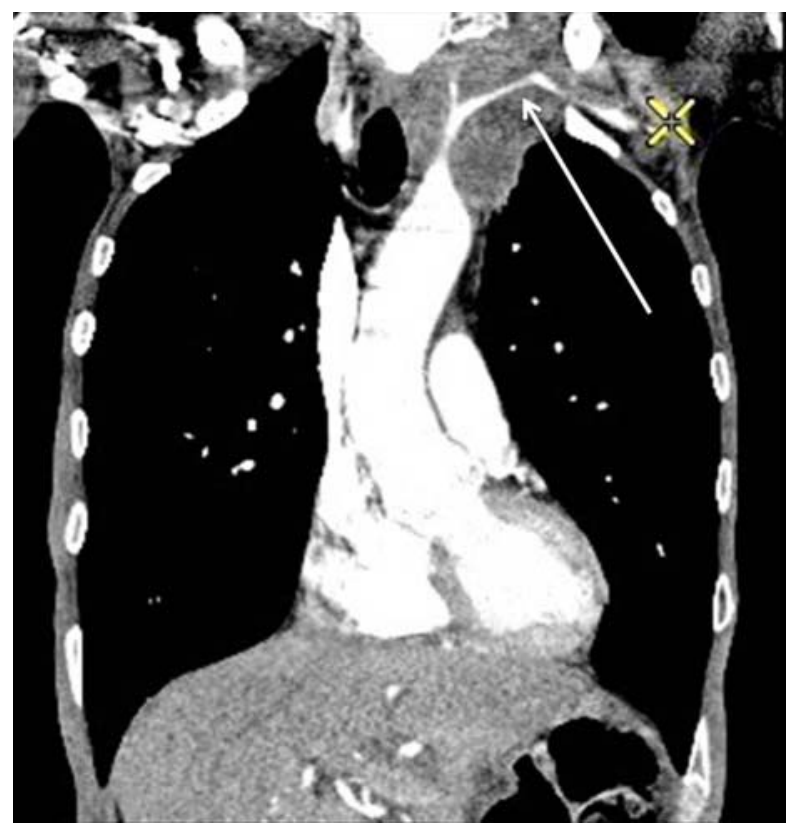

Figure 2 Coronal enhanced CT scan image of the thorax demonstrates a soft-tissue mass $(6.9 \mathrm{~cm} \times 5.4 \mathrm{~cm} \times 7.7 \mathrm{~cm})$, in left lung apex encasing the subclavian artery (white arrows). 


\section{BMJ Case Reports}

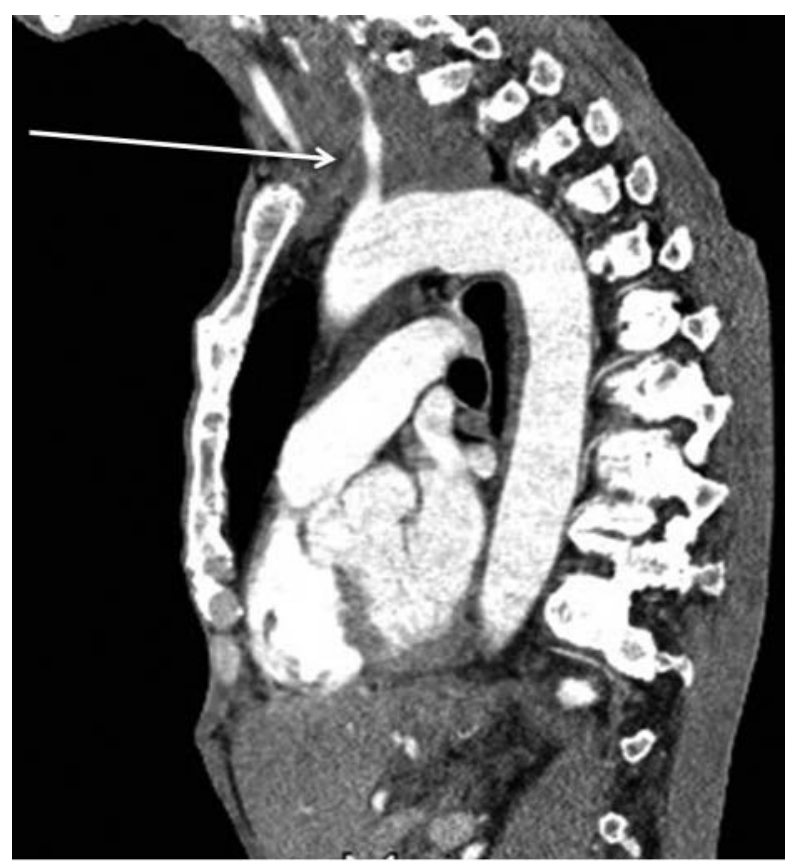

\section{REFERENCES}

1. Fletcher $\mathbf{F}$, Johnston RN, Stradling P. The normal chest radiograph in bronchial carcinoma. BMJ 1976;2:403.1.

2. Yacoub M, Hupert C. Shoulder pain as an early symptom of Pancoast tumour. J Med Soc N J 1980;77:583-6.

3. Pancoast H. Superior pulmonary sulcus tumour. JAMA 1932;99:1391-6.

Figure 3 Sagittal enhanced CT scan image of the thorax shows encased subclavian artery by a Pancoast tumour (white arrows).

This pdf has been created automatically from the final edited text and images.

Copyright 2012 BMJ Publishing Group. All rights reserved. For permission to reuse any of this content visit http://group.bmj.com/group/rights-licensing/permissions.

BMJ Case Report Fellows may re-use this article for personal use and teaching without any further permission.

Please cite this article as follows (you will need to access the article online to obtain the date of publication).

Singh D, Wijeyekoon B. Pancoast tumour. BMJ Case Reports 2012;10.1136/bcr-2012-006285, Published XXX

Become a Fellow of BMJ Case Reports today and you can:

- Submit as many cases as you like

- Enjoy fast sympathetic peer review and rapid publication of accepted articles

- Access all the published articles

- Re-use any of the published material for personal use and teaching without further permission

For information on Institutional Fellowships contact consortiasales@bmjgroup.com

Visit casereports.bmj.com for more articles like this and to become a Fellow 